\title{
The Effect of Pheochromocytoma Treatment on Subclinical Inflammation and Endocrine Function of Adipose Tissue
}

\author{
L. BOŠANSKÁ, O. PETRÁK, T. ZELINKA, M. MRÁZ, J. WIDIMSKÝ Jr, M. HALUZÍK \\ Third Department of Medicine, First Faculty of Medicine, Charles University and General \\ University Hospital, Prague, Czech Republic
}

Received January 10, 2008

Accepted April 3, 2008

On-line July 18, 2008

\begin{abstract}
Summary
The aim of our study was to evaluate the influence of surgical removal of pheochromocytoma on the endocrine function of adipose tissue and subclinical inflammation as measured by circulating C-reactive protein (CRP) levels. Eighteen patients with newly diagnosed pheochromocytoma were included into study. Anthropometric measures, biochemical parameters, serum CRP, leptin, adiponectin and resistin levels were measured at the time of diagnosis and six months after surgical removal of pheochromocytoma. Surgical removal of pheochromocytoma significantly increased body weight, decreased both systolic and diastolic blood pressure, fasting blood glucose and glycated hemoglobin levels. Serum CRP levels were decreased by $50 \%$ six months after surgical removal of pheochromocytoma $(0.49 \pm 0.12$ vs. $0.23 \pm 0.05 \mathrm{mg} / \mathrm{l}, \mathrm{p}<0.05)$ despite a significant increase in body weight. Serum leptin, adiponectin and resistin levels were not affected by the surgery. We conclude that increased body weight in patients after surgical removal of pheochromocytoma is accompanied by an attenuation of subclinical inflammation probably due to catecholamine normalization. We failed to demonstrate an involvement of the changes in circulating leptin, adiponectin or resistin levels in this process.
\end{abstract}

\section{Key words}

Pheochromocytoma • Body weight - Inflammation - Leptin • Adiponectin • Resistin

\section{Corresponding author}

M. Haluzík, Third Department of Medicine, First Faculty of Medicine, Charles University, U Nemocnice 1, 12808 Praha 2, Czech Republic. Fax: $\quad+420224919780$. E-mail: mhalu@lf1.cuni.cz

\section{Introduction}

Chronic low-grade inflammation appears to play an important role in the development of endothelial dysfunction, in atherosclerotic plaque initiation and formation and later on in its instability that may result in a plaque rupture (Jialal et al. 2004, Kvasnička et al. 1997, Raitakari et al. 2005). Recent studies have demonstrated that obesity is accompanied by markedly increased infiltration of adipose tissue by immunocompetent cells that in turn produce increased amount of proinflammatory factors such as tumor necrosis factor- $\alpha$, interleukin- 6 , resistin and many others (Anderlová et al. 2007, Weisberg et al. 2003, Xu et al. 2003). It has been suggested that adipose tissue of obese individuals and, in particular, its visceral compartment, might be a primary site where the subclinical inflammation arises (Neels and Olefsky 2006). Both experimental and clinical studies have demonstrated that numerous hormones of adipose tissue such as adiponectin and resistin, may be directly or indirectly involved in the etiopathogenesis of atherosclerosis (Doležalová et al. 2007, Haluzík et al. 2004, Kawanami et al. 2004, Matsuda et al. 2002, Pischon et al. 2005, Reilly et al. 2005, Shimada et al. 2004).

Patients with a catecholamine-secreting tumor (pheochromocytoma originating from adrenal medulla and functioning paraganglioma arising from sympathetic nervous system associated chromaffin tissue) (Pacák et al. 2005, Zelinka et al. 2007a) represent another group of patients that may suffer from 
early progression of atherosclerosis and higher risk of cardiovascular diseases (Daub 2007, Khorram-Manesh et al. 2005). The exact mechanism of accelerated atherosclerosis in these patients is only partially understood. It probably includes high blood pressure with its increased variability or diminished diurnal variation (Zelinka et al. 2004), disturbances in glucose metabolism and possibly other factors such as increased inflammation markers relative to both healthy subjects and patients with primary aldosteronism (Zelinka et al. $2007 b$ ). Previous in vitro studies have demonstrated that increased catecholamine levels can markedly modulate the endocrine function of adipose tissue (Bottner et al. 1999, Cong et al. 2007).

Here we tested the hypothesis that catecholamine-induced perturbations in endocrine function of adipose tissue may contribute to disturbed metabolic profile in patients with pheochromocytoma and assessed the influence of operational removal of pheochromocytoma on the metabolic parameters and on the endocrine function of adipose tissue.

\section{Patients and Methods}

\section{Patients}

Eighteen patients (11 men and 7 women) with pheochromocytoma were included into study. All patients were examined during hospitalization in the Third Department of Medicine, First Faculty of Medicine, Charles University and General University Hospital, Prague. The baseline examination was performed at the time of pheochromocytoma diagnosis. The diagnosis of pheochromocytoma was based on elevated 24-h urine catecholamines or metanephrines (analysis performed by means of high-performance liquid chromatography on Agilent 1100, Agilent Technologies, Santa Clara, CA, USA) and positive imaging study with computed tomography or magnetic resonance. All subjects underwent surgical removal of the tumor and the diagnosis was confirmed on histopathology.

The second examination of subjects free of disease recurrence was performed at least six months after adrenalectomy. No hypolipidemic, hormonal treatment or treatment affecting food intake was given. Patients with coronary heart disease, stroke, renal failure or acute infectious diseases were excluded from the study. All patients were informed about the purpose of the study and provided their informed consent to participate. The study was approved by the Human Ethical Review Committee, First Faculty of Medicine and General University Hospital, Prague, Czech Republic, and was performed in accordance with the guidelines proposed in the Declaration of Helsinki.

\section{Anthropometric examination and blood sampling}

All patients were measured and weighed and the body mass index (BMI) was calculated. Casual blood pressure (BP) values were obtained in the sitting position using a standard sphygmomanometer. Blood pressure monitoring for $24 \mathrm{~h}$ was performed by means of an oscillometric device SpaceLabs 90207 (SpaceLabs Medical, Richmond, WA, USA) which was set to measure blood pressure every $20 \mathrm{~min}$ during the day (from 6:00 to $22: 00 \mathrm{~h}$ ) and every $30 \mathrm{~min}$ during the night (from 22:00 to 6:00 h).

Blood samples were withdrawn from all patients after an overnight fasting. Serum was obtained by centrifugation and the samples were subsequently stored in aliquots at $-70{ }^{\circ} \mathrm{C}$ until further analysis.

\section{Hormonal and biochemical assays}

Plasma insulin concentrations were measured by commercial radioimmunoassay kit (CIS Bio International, Gif-sur-Yvette, France). Serum leptin concentrations were determined by commercial double sandwich ELISA kit (BioVendor, Brno, Czech Republic). Serum adiponectin concentrations were measured by commercial RIA kit (Linco Research, Inc., St. Charles, MO, USA). Serum resistin concentrations were measured by commercial ELISA kit (BioVendor, Brno, Czech Republic). CRP levels were measured by Ultra-Sensitive C-Reactive Protein ELISA kit (DSL, Oxon, UK). Biochemical parameters were measured by standard laboratory methods in the Department of Clinical Biochemistry of the General University Hospital.

\section{Statistical analysis}

For the statistical analysis the SigmaStat software (Jandel Scientific, San Rafael, CA USA) was used. Results are expressed as means \pm S.E.M. Paired $t$-test was used to compare the values of patients before and after treatment. Unpaired $t$-test or Mann-Whitney Rank Sum Test was used to calculate gender-related differences. The relationships between the data were calculated by Pearson or Spearman correlation test. 
Table 1. Characteristics of patients with pheochromocytoma before and after treatment.

\begin{tabular}{|c|c|c|c|}
\hline & $\begin{array}{c}\text { Before treatment } \\
\qquad \mathbf{n}=\mathbf{1 8}\end{array}$ & $\begin{array}{l}\text { After treatment } \\
\quad n=18\end{array}$ & $\mathbf{p}<$ \\
\hline Gender (woman/man) & $7 / 11$ & $7 / 11$ & \\
\hline Age (years) & $45.7 \pm 2.9$ & $46.5 \pm 2.7$ & \\
\hline$B M I\left(\mathrm{~kg} / \mathrm{m}^{2}\right)$ & $24.3 \pm 0.8$ & $25.5 \pm 0.9 * *$ & 0.001 \\
\hline Systolic blood pressure (SBP, $\mathrm{mm} \mathrm{Hg}$ ) & $137 \pm 4$ & $126 \pm 3 *$ & 0.05 \\
\hline Diastolic blood pressure (DBP, $\mathrm{mm} \mathrm{Hg}$ ) & $84 \pm 4$ & $82 \pm 2$ & NS \\
\hline SBP during 24-h monitoring ( $\mathrm{mm} \mathrm{Hg}$ ) & $134 \pm 4$ & $118 \pm 2 * *$ & 0.001 \\
\hline DBP during 24-h monitoring ( $\mathrm{mm} \mathrm{Hg}$ ) & $83 \pm 3$ & $74 \pm 1 *$ & 0.01 \\
\hline Total cholesterol (mmol/l) & $5.7 \pm 0.3$ & $5.5 \pm 0.3$ & NS \\
\hline Serum triglycerides (mmol/l) & $1.5 \pm 0.2$ & $1.4 \pm 0.2$ & NS \\
\hline HDL cholesterol (mmol/l) & $1.6 \pm 0.06$ & $1.4 \pm 0.06$ & NS \\
\hline Fasting blood glucose (mmol/l) & $7.0 \pm 0.4$ & $4.7 \pm 0.1$ & 0.001 \\
\hline Glycated hemoglobin (\%) & $4.5 \pm 0.3$ & $3.8 \pm 0.2$ & 0.01 \\
\hline Plasma insulin ( $\mu I U / m l)$ & $19.2 \pm 2.1$ & $15.5 \pm 1.5$ & NS \\
\hline Urinary epinephrine levels (nmol/g creat) & $377.9 \pm 155$ & $19.1 \pm 2.8$ & 0.05 \\
\hline Urinary rorepinephrine levels (nmol/g creat) & $2676 \pm 438$ & $176.9 \pm 15.3$ & 0.001 \\
\hline
\end{tabular}

Values are means \pm SEM.

Table 2. Serum levels of C-reactive protein, leptin, adiponectin and resistin in patients with pheochromocytoma before and after treatment.

\begin{tabular}{lccc}
\hline & $\begin{array}{c}\text { Before treatment } \\
\mathbf{n}=\mathbf{1 8}\end{array}$ & $\begin{array}{c}\text { After treatment } \\
\mathbf{n}=\mathbf{1 8}\end{array}$ & \\
\hline CRP $(\mathrm{mg} / \mathrm{l})$ & $0.492 \pm 0.123$ & $0.235 \pm 0.051$ & $\mathrm{p}<0.05$ \\
Leptin $(\mathrm{ng} / \mathrm{ml})$ & $6.76 \pm 1.78$ & $8.79 \pm 2.86$ & $\mathrm{NS}$ \\
Adiponectin $(\mu \mathrm{g} / \mathrm{ml})$ & $20.01 \pm 2.49$ & $18.34 \pm 2.49$ & $\mathrm{NS}$ \\
Resistin $(\mathrm{ng} / \mathrm{ml})$ & $5.34 \pm 0.5$ & $5.56 \pm 0.55$ & $\mathrm{NS}$ \\
\hline
\end{tabular}

Values are means \pm SEM.

\section{Results}

Anthropometry, biochemical parameters and blood pressure in patients with pheochromocytoma before and after treatment

Baseline and postoperational parameters of patients with pheochromocytoma are shown in Table 1. At baseline, systolic and diastolic blood pressure, serum total cholesterol, fasting blood glucose and serum glycated hemoglobin were above the normal limits of our laboratory. Surgical removal of pheochromocytoma significantly increased BMI, decreased average systolic and average diastolic blood pressure as measured by $24-\mathrm{h}$ monitoring. The total cholesterol, HDL cholesterol and triglyceride levels did not change after the treatment. The removal of pheochromocytoma significantly decreased fasting glucose levels and the glycated hemoglobin levels. Insulin levels tended to decrease after operation, but the difference did not reach the statistical significance.

Serum CRP, leptin, adiponectin and resistin levels in patients with pheochromocytoma before and after treatment

The surgical removal of pheochromocytoma significantly decreased C-reactive protein (CRP) levels (Table 2). On the contrary, no significant changes in serum leptin, adiponectin and resistin levels were found 


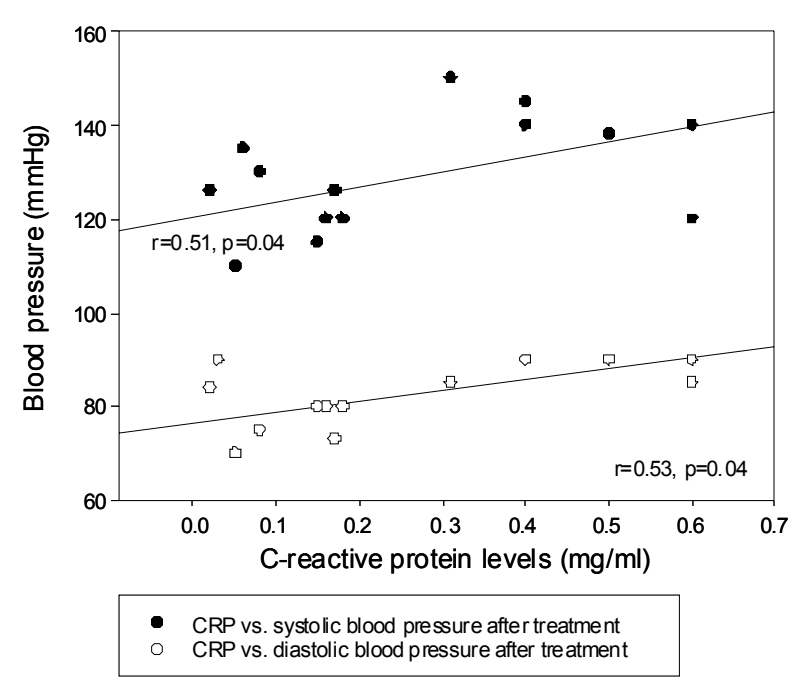

Fig. 1. Correlation of serum CRP levels with systolic (black circles) and diastolic (open circles) blood pressure in patients with pheochromocytoma after the surgery.

after surgical treatment despite a significant increase in BMI (Table 2). When comparing leptin levels according to gender, there were higher leptin levels in women than in men $(12.4 \pm 3.6$ vs. $3.2 \pm 0.8 \mathrm{ng} / \mathrm{ml}$ before surgery, $\mathrm{p}=0.046$ ). The same tendency on the borderline of statistical significance was found after the surgery (16.7 \pm 6.4 vs. $3.7 \pm 0.8 \mathrm{ng} / \mathrm{ml}, \mathrm{p}=0.052)$.

The relationship of adipokines to anthropometric parameters, blood pressure, CRP and biochemical variables

In patients before the operation, serum leptin levels correlated positively with age $(r=0.70, p=0.001)$, BMI $(\mathrm{r}=0.50, \mathrm{p}=0.01)$, triglycerides $(\mathrm{r}=0.59, \mathrm{p}=0.01)$ and insulin levels $(\mathrm{r}=0.54, \mathrm{p}=0.02)$. After the surgery serum leptin levels correlated positively with age $(\mathrm{r}=0.67, \quad \mathrm{p}=0.02), \quad$ BMI $\quad(\mathrm{r}=0.60, \quad \mathrm{p}=0.01) \quad$ and triglyceride levels $(\mathrm{r}=0.50, \mathrm{p}=0.04)$. Serum leptin levels negatively correlated with 24 -h diastolic blood pressure before surgery $(\mathrm{r}=-0.59, \mathrm{p}=0.011)$. No other significant relationships of leptin with other parameters (including urinary epinephrine and norepinephrine levels) were found. Serum resistin levels after surgery correlated positively with total cholesterol levels $(r=0.61$, $\mathrm{p}=0.007)$. No significant correlations between CRP and the adipokines were found. CRP levels correlated positively with both systolic and diastolic blood pressure ( $\mathrm{r}=0.51, \mathrm{p}=0.04$ and $\mathrm{r}=0.53, \mathrm{p}=0.04$, respectively) (Fig. $1)$, with total cholesterol $(\mathrm{r}=0.65, \mathrm{p}=0.01)$, triglyceride levels $(\mathrm{r}=0.55, \mathrm{p}=0.03)$ and 24 -h urinary epinephrine levels $(r=0.56, p=0.02)$ in patients after surgery. No other significant relationships between CRP, adipokines, catecholamines and other parameters studied were found.

\section{Discussion}

Our study showed that successful treatment of pheochromocytoma led to a significant weight gain accompanied by decreased blood glucose, glycated hemoglobin levels together with attenuation of subclinical inflammation as measured by C-reactive protein levels. The most important finding of this study, however, was the dissociation between subclinical inflammatory reaction, weight gain and the endocrine function of adipose tissue in patients with pheochromocytoma after surgical removal of the tumor. Overproduction of catecholamines in patients with pheochromocytoma is accompanied by a higher basal metabolic rate (Gifford et al. 1964). Therefore its successful removal leads to a body weight gain probably due to an increase of body fat content resulting from the shift of energy balance. Here we show that the increase in body weight was accompanied by attenuated subclinical inflammatory response as measured by circulating CRP levels. This finding is rather surprising since numerous studies have linked increased CRP levels to increased BMI in obesity (Haffner 2003a,b, Stoll and Bendszus 2006). On the contrary, low BMI in malnourished patients such as those with anorexia nervosa is accompanied by lower CRP relative to normal weight subjects (Doležalová et al. 2007). Based on the previous studies, it could have been expected that the increase in body weight would rather promote the production of proinflammatory factors in adipose tissue (Anderlová et al. 2006, Cancello et al. 2005). On the other hand, the increase in BMI in our study was rather mild and it still remained within the normal or slightly overweight limits. Therefore its influence on the subclinical inflammation could have been relatively small. More likely explanation of the dissociation of body weight gain and simultaneous decrease in CRP levels probably lies in the direct effect of increased catecholamines on CRP and/or the possible influence of increased blood pressure on CRP levels. The possible direct influence of catecholamines on CRP is further supported by a positive correlation between CRP and 24-h urinary epinephrine levels after the surgery.

To assess directly the changes of endocrine function of adipose tissue, we measured serum concentrations of three adipose tissue-derived hormones known to affect body weight and/or systemic 
inflammation - leptin, adiponectin and resistin both before and after surgical treatment of pheochromocytoma. Decreased adiponectin levels have been previously linked to increased risk of insulin resistance and atherosclerosis (Shimada et al. 2004, Yamauchi et al. 2003, Yang et al. 2001), while the opposite was found for circulating resistin levels (Degawa-Yamauchi et al. 2003, Pischon et al. 2005, Reilly et al. 2005, Ukkola 2002). Serum leptin levels appear to correlate closely with body fat content which is increased in patients with obesity relative to lean subjects (Maffei et al. 1995, Tartaglia et al. 1995). Surprisingly, none of the three measured adipose tissue-derived hormones was significantly affected by surgical removal of pheochromocytoma. This finding argues against the direct involvement of these hormones in the suppression of systemic inflammatory reaction in patients with pheochromocytoma.

In contrast to catecholamine inhibitory effects on leptin production in experimental (Kosaki et al. 1996, Trayhurn et al. 1996) and also in some clinical studies (Wocial et al. 2002) we did not observe significant effect of pheochromocytoma removal on serum leptin levels.
This lack of effect might be due to downregulation of functional adrenergic receptors and development of tolerance of adipose tissue to regulatory action of catecholamines (Bottner et al. 1999) or due to other yet unknown mechanism.

In conclusion, our study demonstrated that the weight gain in patients after surgical removal of pheochromocytoma was accompanied by a significant decrease of CRP levels. The drop of CRP may thus reflect positive effects of pheochromocytoma removal on atherosclerosis progression and cardiovascular risk or rather the discontinuation of the effect of increased catecholamine levels on CRP production. Finally, we failed to demonstrate a direct involvement of the changes in serum leptin, adiponectin or resistin levels in this process.

\section{Conflict of Interest}

There is no conflict of interest.

\section{Acknowledgements}

This study was supported by MZO VFN 2005, MSM 21620808 and IGA 8302-5.

\section{References}

ANDERLOVÁ K, DOLEŽALOVÁ R, HOUSOVÁ J, BOŠANSKÁ L, HALUZÍKOVÁ D, KŘEMEN J, ŠKRHA J, HALUZÍK M: Influence of PPAR-alpha agonist fenofibrate on insulin sensitivity and selected adipose tissuederived hormones in obese women with type 2 diabetes. Physiol Res 56: 579-586, 2007.

ANDERLOVÁ K, KŘEMEN J, DOLEŽALOVÁ R, HOUSOVÁ J, HALUZÍKOVÁ D, KUNEŠOVÁ M, HALUZÍK M: The influence of very-low-calorie-diet on serum leptin, soluble leptin receptor, adiponectin and resistin levels in obese women. Physiol Res 55: 277-283, 2006.

BOTTNER A, EISENHOFER G, TORPY DJ, EHRHART-BORNSTEIN M, KEISER HR, CHROUSOS GP, BORNSTEIN SR: Lack of leptin suppression in response to hypersecretion of catecholamines in pheochromocytoma patients. Metabolism 48: 543-545, 1999.

CANCELLO R, HENEGAR C, VIGUERIE N, TALEB S, POITOU C, ROUAULT C, COUPAYE M, PELLOUX V, HUGOL D, BOUILLOT JL, BOULOUMIE A, BARBATELLI G, CINTI S, SVENSSON PA, BARSH GS, ZUCKER JD, BASDEVANT A, LANGIN D, CLEMENT K: Reduction of macrophage infiltration and chemoattractant gene expression changes in white adipose tissue of morbidly obese subjects after surgeryinduced weight loss. Diabetes 54: 2277-2286, 2005.

CONG L, CHEN K, LI J, GAO P, LI Q, MI S, WU X, ZHAO AZ: Regulation of adiponectin and leptin secretion and expression by insulin through a PI3K-PDE3B dependent mechanism in rat primary adipocytes. Biochem $J \mathbf{4 0 3}$ : 519-525, 2007.

DAUB KF: Pheochromocytoma: challenges in diagnosis and nursing care. Nurs Clin North Am 42: 101-111, 2007.

DEGAWA-YAMAUCHI M, BOVENKERK JE, JULIAR BE, WATSON W, KERR K, JONES R, ZHU Q, CONSIDINE RV: Serum resistin (FIZZ3) protein is increased in obese humans. $J$ Clin Endocrinol Metab 88: 5452-5455, 2003. 
DOLEŽALOVÁ R., HALUZÍK MM, BOŠANSKÁ L., LACINOVÁ Z., KASALOVÁ Z., STULC T., HALUZÍK M: Effect of PPAR-gamma agonist treatment on markers of endothelial dysfunction in patients with type 2 diabetes mellitus. Physiol Res 56: 741-748, 2007.

DOLEŽALOVÁ R, LACINOVÁ Z, DOLÍNKOVÁ M, KLEIBLOVÁ P, HALUZÍKOVÁ D, HOUSA D, PAPEŽOVÁ H, HALUZÍK M: Changes of endocrine function of adipose tissue in anorexia nervosa: comparison of circulating levels versus subcutaneous mRNA expression. Clin Endocrinol (Oxf) 67: 674-678, 2007.

GIFFORD RW, JR., KVALE WF, MAHER FT, ROTH GM, PRIESTLEY JT: Clinical features, diagnosis and treatment of pheochromocytoma: a review of 76 cases. Mayo Clin Proc 39: 281-302, 1964.

HAFFNER SM: Insulin resistance, inflammation, and the prediabetic state. Am J Cardiol 92: 18J-26J, 2003a.

HAFFNER SM: Pre-diabetes, insulin resistance, inflammation and CVD risk. Diabetes Res Clin Pract 61 (Suppl 1): S9-S18, 2003b.

HALUZÍK M, PAŘÍZKOVÁ J, HALUZÍK MM: Adiponectin and its role in the obesity-induced insulin resistance and related complications. Physiol Res 53: 123-129, 2004.

JIALAL I, DEVARAJ S, VENUGOPAL SK: C-reactive protein: risk marker or mediator in atherothrombosis? Hypertension 44: 6-11, 2004.

KAWANAMI D, MAEMURA K, TAKEDA N, HARADA T, NOJIRI T, IMAI Y, MANABE I, UTSUNOMIYA K, NAGAI R: Direct reciprocal effects of resistin and adiponectin on vascular endothelial cells: a new insight into adipocytokine-endothelial cell interactions. Biochem Biophys Res Commun 314: 415-419, 2004.

KHORRAM-MANESH A, AHLMAN H, NILSSON O, FRIBERG P, ODEN A, STENSTROM G, HANSSON G, STENQUIST O, WANGBERG B, TISELL LE, JANSSON S: Long-term outcome of a large series of patients surgically treated for pheochromocytoma. J Intern Med 258: 55-66, 2005.

KOSAKI A, YAMADA K, KUZUYA H: Reduced expression of the leptin gene (ob) by catecholamine through a G(S) protein-coupled pathway in 3T3-L1 adipocytes. Diabetes 45: 1744-1749, 1996.

KVASNIČKA J, ŠKRHA J, PERUŠIČOVÁ J, KVASNIČKA T, MARKOVÁ M, UMLAUFOVÁ A, PECEN L: The occurrence of the cardiovascular risk factors - fibrinogen, t-PA, PAI-1, in insulin-dependent diabetes mellitus (IDDM) and in non-insulin-dependent diabetes mellitus (NIDDM) Cor Vasa 39: 146-150, 1997.

MAFFEI M, HALAAS J, RAVUSSIN E, PRATLEY RE, LEE GH, ZHANG Y, FEI H, KIM S, LALLONE R, RANGANATHAN S, KERN PA, FRIEDMAN JM: Leptin levels in human and rodent: measurement of plasma leptin and ob RNA in obese and weight-reduced subjects. Nat Med 1: 1155-1161, 1995.

MATSUDA M, SHIMOMURA I, SATA M, ARITA Y, NISHIDA M, MAEDA N, KUMADA M, OKAMOTO Y, NAGARETANI H, NISHIZAWA H, KISHIDA K, KOMURO R, OUCHI N, KIHARA S, NAGAI R, FUNAHASHI T, MATSUZAWA Y: Role of adiponectin in preventing vascular stenosis. The missing link of adipo-vascular axis. J Biol Chem 277: 37487-3791, 2002.

NEELS JG, OLEFSKY JM: Inflamed fat: what starts the fire? J Clin Invest 116: 33-35, 2006.

PACAK K, ILIAS I, ADAMS KT, EISENHOFER G: Biochemical diagnosis, localization and management of pheochromocytoma: focus on multiple endocrine neoplasia type 2 in relation to other hereditary syndromes and sporadic forms of the tumour. J Intern Med 257: 60-68, 2005.

PISCHON T, BAMBERGER CM, KRATZSCH J, ZYRIAX BC, ALGENSTAEDT P, BOEING H, WINDLER E: Association of plasma resistin levels with coronary heart disease in women. Obes Res 13: 1764-1771, 2005.

RAITAKARI M, MANSIKKANIEMI K, MARNIEMI J, VIIKARI JS, RAITAKARI OT: Distribution and determinants of serum high-sensitive C-reactive protein in a population of young adults: The Cardiovascular Risk in Young Finns Study. J Intern Med 258: 428-434, 2005.

REILLY MP, LEHRKE M, WOLFE ML, ROHATGI A, LAZAR MA, RADER DJ: Resistin is an inflammatory marker of atherosclerosis in humans. Circulation 111: 932-939, 2005.

SHIMADA K, MIYAZAKI T, DAIDA H: Adiponectin and atherosclerotic disease. Clin Chim Acta 344: 1-12, 2004.

STOLL G, BENDSZUS M: Inflammation and atherosclerosis: novel insights into plaque formation and destabilization. Stroke 37: 1923-1932, 2006.

TARTAGLIA LA, DEMBSKI M, WENG X, DENG N, CULPEPPER J, DEVOS R, RICHARDS GJ, CAMPFIELD LA, CLARK FT, DEEDS J, et al.: Identification and expression cloning of a leptin receptor, OB-R. Cell $\mathbf{8 3}$ : 1263-1271, 1995. 
TRAYHURN P, DUNCAN JS, RAYNER DV, HARDIE LJ: Rapid inhibition of ob gene expression and circulating leptin levels in lean mice by the beta 3-adrenoceptor agonists BRL 35135A and ZD2079. Biochem Biophys Res Commun 228: 605-610, 1996.

UKKOLA O: Resistin - a mediator of obesity-associated insulin resistance or an innocent bystander? Eur J Endocrinol 147: 571-574, 2002.

WEISBERG SP, MCCANN D, DESAI M, ROSENBAUM M, LEIBEL RL, FERRANTE AW, JR.: Obesity is associated with macrophage accumulation in adipose tissue. J Clin Invest 112: 1796-1808, 2003.

WOCIAL B, IGNATOWSKA-SWITALSKA H, BERENT H, DUTKIEWICZ-RACZKOWSKA M, KUCZYNSKA K, CHODAKOWSKA J, FELTYNOWSKI T, JANUSZEWICZ W, SZOSTEK M, CIESLA W: Do catecholamines influence the level of plasma leptin in patients with phaeochromocytoma? Br J Biomed Sci 59: 141-144, 2002.

XU H, BARNES GT, YANG Q, TAN G, YANG D, CHOU CJ, SOLE J, NICHOLS A, ROSS JS, TARTAGLIA LA, CHEN H: Chronic inflammation in fat plays a crucial role in the development of obesity-related insulin resistance. J Clin Invest 112: 1821-1830, 2003.

YAMAUCHI T, KAMON J, WAKI H, IMAI Y, SHIMOZAWA N, HIOKI K, UCHIDA S, ITO Y, TAKAKUWA K, MATSUI J, TAKATA M, ETO K, TERAUCHI Y, KOMEDA K, TSUNODA M, MURAKAMI K, OHNISHI Y, NAITOH T, YAMAMURA K, UEYAMA Y, FROGUEL P, KIMURA S, NAGAI R, KADOWAKI T: Globular adiponectin protected ob/ob mice from diabetes and ApoE-deficient mice from atherosclerosis. J Biol Chem 278: 2461-2468, 2003.

YANG WS, LEE WJ, FUNAHASHI T, TANAKA S, MATSUZAWA Y, CHAO CL, CHEN CL, TAI TY, CHUANG LM: Weight reduction increases plasma levels of an adipose-derived anti-inflammatory protein, adiponectin. J Clin Endocrinol Metab 86: 3815-3819, 2001.

ZELINKA T, EISENHOFER G, PACÁK K: Pheochromocytoma as a catecholamine producing tumor: implications for clinical practice. Stress 10: 195-203, 2007a.

ZELINKA T, PETRÁK O, ŠTRAUCH B, HOLAJ R, KVASNIČKA J, MAZOCH J, PACÁK K, WIDIMSKÝ J, JR.: Elevated inflammation markers in pheochromocytoma compared to other forms of hypertension. Neuroimmunomodulation 14: 57-64, 2007b.

ZELINKA T, ŠTRAUCH B, PECEN L, WIDIMSKÝ J, JR.: Diurnal blood pressure variation in pheochromocytoma, primary aldosteronism and Cushing's syndrome. J Hum Hypertens 18: 107-111, 2004. 